ENTREPRENEURSHIP AND SUSTAINABILITY ISSUES

ISSN 2345-0282 (online) http://jssidoi.org/jesi/

2020 Volume 7 Number 4 (June)

http://doi.org/10.9770/jesi.2020.7.4(41)
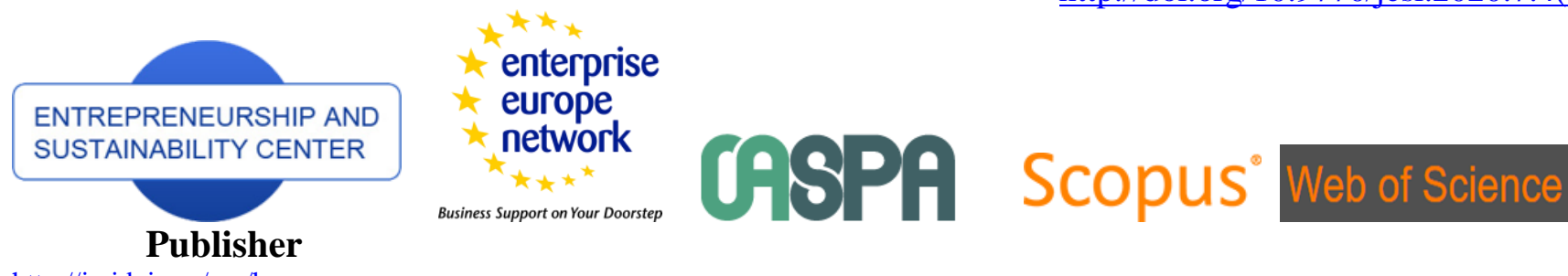

http://jssidoi.org/esc/home

Business Support on Your Doorstep

1) Clarivate

Analytics

\title{
SUSTAINABLE DEVELOPMENT OF CROP PRODUCTION WITH ELEMENTS OF PRECISION AGRICULTURE IN NORTHERN KAZAKHSTAN*
}

\author{
Altynay B. Abuova ${ }^{1}$, Saniya A. Tulkubayeva ${ }^{2}$, Yuriy V. Tulayev ${ }^{3}$, Svetlana V. Somova ${ }^{4}$, \\ Maigul Zh. Kizatova ${ }^{5}$ \\ ${ }^{1}$ Zhangir Khan West Kazakhstan Agrarian-Technical University \\ 51 Zhangir Khan Str., Uralsk, West-Kazakhstan region, 090009, The Republic of Kazakhstan \\ 2.3.4 «Agricultural experimental station «Zarechnoye» Limited Liability Company \\ 12 Yubileinaya Str., Zarechnoye village, Kostanay district, Kostanay region, \\ 111108, Republic of Kazakhstan \\ ${ }^{5}$ Kazakh National University named after S. Asfendiyarov, \\ 94 Tole bi str., Almaty, 050012, Republic of Kazakhstan \\ E-mails: ${ }^{1}$ a burkhatovna@mail.ru; ${ }^{2}$ tulkubaeva@mail.ru; ${ }^{3}$ yurii27@yandex.kz; ${ }^{4}$ somik11-84@mail.ru; \\ ${ }^{5}$ kizatova@mail.ru
}

Received 18 November 2019; accepted 25 April 2020; published 30 June 2020

\begin{abstract}
The Agricultural Experimental Station «Zarechnoye» LLP (AES «Zarechnoye» LLP, Kostanay region, Kazakhstan) has always been the initiator of introduction and dissemination of advanced innovative technologies; in this regard, the agriculture has been identified as the basis for the introduction of digitalization elements, i.e. precision agriculture. The use of elements of the precision agriculture system by the AES «Zarechnoye» LLP, the use of modern technology equipped with an automatic driving system, a differential fertilizer application system and plant protection products ensured a guaranteed yield with high technological indicators in an extremely arid year. The obtained yield level of grain crops exceeded the average regional level by $79.7 \%$. An economic model for the introduction of precision agriculture elements for the farm «Agrofirma Karkyn» LLP with medium technical equipment, indicating the costs of applying the developed technologies per 1 ha, was built. The analysis of economic return was carried out as a result of increased productivity with indicating the payback period. The production and economic indicators of the surveyed farm in the Kostanay region, obtained as a result of constructing financial and economic models taking into account the introduction of precision agriculture elements, are presented. Based on the constructed financial and economic models, the calculations showed that the introduction of precision agriculture elements will reduce production costs for wheat growing to 1.6 thousand tenge per 1 ha of cultivated area, or $4 \%$ of all production costs. The payback period for simulated improvements in the implementation of precision agriculture elements for the farm, while maintaining the current processing area, will be 4.4 years. The data obtained during the study can be used by agricultural producers to develop measures to increase productivity and reduce the cost of production, as well as by government agencies to improve measures of state support and regulation in the field of agriculture, aimed at digitalization, the introduction of precision agriculture elements and increasing the competitiveness of agricultural production.
\end{abstract}

\footnotetext{
* This article has been prepared based on the results of the research conducted as part of the scientific and technical programme No. BR06349568 «Transfer and adaptation of precision agriculture technologies for crop production on the principle of "demonstration farms (testing areas)》 in the Kostanay region», funded by the Ministry of Agriculture of the Republic of Kazakhstan for 2018-2020.
} 


\section{ENTREPRENEURSHIP AND SUSTAINABILITY ISSUES}

ISSN 2345-0282 (online) http://jssidoi.org/jesi/

2020 Volume 7 Number 4 (June)

http://doi.org/10.9770/jesi.2020.7.4(41)

Keywords: precision agriculture; crop management; IT-technologies; information systems; electronic field map; agrochemical field inspection; efficiency; comparative analysis; economic implementation model

Reference to this paper should be made as follows: Abuova, A.B., Tulkubayeva, S.A., Tulayev, Y.V., Somova, S.V.,Kizatova, M.Zh. 2020. Sustainable development of crop production with elements of precision agriculture in Northern Kazakhstan. Entrepreneurship and Sustainability Issues, 7(4), 3200-3214. https://doi.org/10.9770/jesi.2020.7.4(41)

JEL Classifications: Q16, Q30

\section{Introduction}

One of the basic elements of sustainable technologies in agriculture is "precision agriculture» (or as it is sometimes called «precision agriculture»). Precision agriculture is the management of crop productivity, taking into account the in-field variability of the habitat of plants. Relatively speaking, this is the optimal control for each square meter of the field. The purpose of such a management is to maximize profits, subject to the optimization of agricultural production, preserving economic and natural resources. This opens up real opportunities for the production of quality products and environmental conservation. As international experience shows, this approach provides a much greater economic effect and, most importantly, allows farmers to increase the reproduction of soil fertility and the level of ecological purity of agricultural products.

Currently, rising prices for seeds, mineral fertilizers, plant protection products, machinery and other means of production in agriculture lead to the need to increase the efficiency of their use. The managers and agricultural specialists are faced with the task of increasing the level of management, as an important factor for achieving effective agriculture. The task is solved by means of a new direction called 'precision agriculture', which is currently gaining ground in many countries (Yakushev et al., 2007; Allahyari et al., 2016; Far et al., 2018).

The development of modern information technology is the basis of the transition to precision agriculture. The considered elements of precision agriculture are most important for agricultural commodity producers. The development of the precision agriculture system is an urgent task, since it helps the industry to reach a qualitatively new level of production, which, with certain changes in state policy supporting agriculture, will allow farmers to compete with foreign enterprises (Sychev et al., 2011; Higgins et al., 2017).

The aim of this work is to establish the effectiveness of the introduction of precision agriculture elements in the farms of Northern Kazakhstan. The results of this study will form the basis of recommendations on creating a competitive crop production, reducing production costs for field crop producers, improving state support measures in crop production, and will provide access to data on the activities of agricultural producers for foreign and Kazakhstani research organizations, researchers and other concerned parties when conducting marketing and science researches.

\section{Review of literature}

The issues of reforming agricultural complex of the country, introducing precision agriculture technology that contribute to increasing soil fertility and obtaining stable crops at minimum cost are relevant for the Republic of Kazakhstan. The most important stage of the transition to precision agriculture is the assessment of the spatial heterogeneity of the fields and the calculation of the doses of differential fertilizer application. Obtaining operational information on the properties of arable soils is necessary for monitoring and timely assessment of their condition. In precision agriculture, such information is used for spatial differentiation of tillage technologies, fertilizer, ameliorant, plant protection products and growth regulators application, which contributes to the implementation of more effective crop management, reduce the environmental load, reduce the costs of 


\section{ENTREPRENEURSHIP AND SUSTAINABILITY ISSUES}

ISSN 2345-0282 (online) http://jssidoi.org/jesi/

2020 Volume 7 Number 4 (June)

http://doi.org/10.9770/jesi.2020.7.4(41)

agricultural production and use the resource potential of agricultural land more productively (Nukeshev, 2015). The differential application of fertilizers consists in the fact that fertilizers are applied not with a single dose to the entire field being treated, but taking into account the needs of individual elementary sections of the field in fertilizer elements. In this case, the application dose and the ratio of fertilizer elements are selected so that the payback of fertilizers is maximized and environmental pollution is minimized (Nukeshev et al., 2014; Kurishbaev et al., 2012). A practical, economic and environmental rationale for the targeted application of fungicides is the differentiation of consumption rates in heterogeneous crops of grain, rape or other crops, depending on the size of the plant surface. Therein the following goal is pursued: to ensure uniform coverage of the plant surface with fungicides throughout the field, taking into account differences in growth and development at different points of the same field (Shpaar et al., 2009). For differential application of plant protection products, systems operating in real time are of practical importance. All technological steps are carried out at the same time, that is, data collection, processing and control of the sprayer are carried out in one working pass. To implement this technological approach, various sensor systems and electronically controlled sprayers with direct and multichamber power are offered on the market (Truflyak et al., 2016). One of the problems of setting and monitoring field experiments is the operational monitoring of plant vegetation during the experiment. The most promising method for remote monitoring of industrial field experience is the use of Earth remote sensing (ERS) (Tugarinov et al., 2018).

In recent years, satellite imagery has been widely used to solve problems associated with the prediction of the spatial distribution of environmental data. However, this source of information has a number of disadvantages, the main of which are the following: high cost of images; limiting the possibility of obtaining images in a short time and with the necessary frequency; the need for decryption of images; errors caused by weather conditions, cloudiness and haze (Truflyak et al., 2015; Mitrofanov et al., 2018). In this regard, a promising alternative to this method is the use of radio-controlled unmanned aerial vehicles (UAVs). The use of UAVs for monitoring and collecting remote sensing data can significantly reduce the cost of research and speed up the process of obtaining relevant data with high temporal and spatial resolution (Yakushev, 2002; Pestunov et al., 2018; Srivastava et al., 2019; Maes et al., 2019; Abuova et al., 2019).

In Europe, space technologies in agriculture are widely used from GPS which allow you to determine the location of equipment, organize parallel driving, control the operation of actuators, to the use of images in the nearinfrared range to determine the heterogeneity of crop growth, their further alignment using systems and precision fertilizer units. Most agricultural enterprises in Germany are equipped with computers and modern technology. Soil maps and aerial photographs are available to any entrepreneur (Truflyak, 2016).

According to some scientists, when comparing the NDVI indicators obtained by means of remote and ground surveys during a three-year observation, it was found that the largest discrepancies between the results of ground and remote assessment for cereals were noted in the initial phases of development (25-33\%), and the smallest - at the time of reaching the peak of NDVI in the earing phase. In addition to the necessary atmospheric correction procedure, the results of satellite imagery should be calibrated against ground reference objects: a pond, asphalt, ploughed soil without vegetation, crops with different backgrounds of fertilizers. For calibration, a sensor with an active radiation source in the red and infrared spectral regions should be used, for example, GreenSeeker (Hmiminaa et al., 2013; Spitkó et al., 2016).

When introducing precision agriculture technologies in agricultural production, the most popular direction was the use of parallel driving systems. There are three options for the implementation of parallel driving. In the first case, driving the tractor is adjusted by the driver using the steering wheel, which is guided by the indications of the LED or graphic track indicator located in the cab; in the second case, the driving direction of the tractor is supported by a thruster driven by an electric motor mounted on the steering column. In the third version, the adjustment of the driving direction of the tractor is carried out by an actuating mechanism connected to the 


\section{ENTREPRENEURSHIP AND SUSTAINABILITY ISSUES}

ISSN 2345-0282 (online) http://jssidoi.org/jesi/

2020 Volume 7 Number 4 (June)

http://doi.org/10.9770/jesi.2020.7.4(41)

hydraulic system of steering gear (Goltyapin, 2013). Monitoring agricultural yield allows us to identify its heterogeneity for each crop within the field and present it in digital map format. They document what yield indicators are provided for certain sections of the field, and what the range of differences within one field is. Mapping of the yield has received the most practical application in the cultivation of cereals (Truflyak, 2016).

Currently, agricultural enterprises of the Kostanay region apply various technologies using domestic and foreign agricultural equipment. Moreover, the equipment purchased by agricultural producers has model lines with various technical and operational indicators (Agriculture, forestry and fisheries..., 2013; Catalog of tractor factories...). Often, engineering services of economic entities, intending to acquire equipment, are not aware of its technical and technological capabilities (traction capabilities, performance as a part of various units, fuel consumption, etc.) and its options for equipping with instruments and equipment for working in the precision agriculture system from due to lack of scientific and technical information. At the same time, the use of agricultural machinery and expensive digital equipment for purposes other than intended only increases the costs of crop production without solving the problem of increasing labour productivity. This problem can be solved by the rational use of modern tractors, combines and agricultural machines in the precision agriculture system based on scientific and technical information about their capabilities for specific natural-production conditions (Lichman et al., 2016; Leonard, 2016; Baerdemaeker, 2013).

The main results achieved through the application of precision agriculture technologies are as follows (Polshakova, 2017):

1. optimization of the use of consumable materials (cost minimization);

2. increasing the yield and quality of agricultural products;

3. minimization of the negative impact of agricultural production on the environment;

4. land quality improvement;

5. information support for agricultural management.

The table 1 below shows the comparative characteristics of various technologies for the cultivation of agricultural crops (Shilova, 2014).

Table 1. Comparative characteristics of various agricultural cultivation technologies

\begin{tabular}{|c|c|c|c|c|}
\hline Technology & $\begin{array}{l}\text { Technological } \\
\text { characteristics }\end{array}$ & $\begin{array}{c}\text { The essence of } \\
\text { technology }\end{array}$ & Advantages & Disadvantages \\
\hline $\begin{array}{l}\text { Traditional } \\
\text { technology. }\end{array}$ & $\begin{array}{l}\text { In the framework of this } \\
\text { technology reversible } \\
\text { ploughs turning soil } \\
\text { layers are used; centre } \\
\text { ridges and backfurrows } \\
\text { are absent. }\end{array}$ & $\begin{array}{l}\text { The use of } \\
\text { agricultural } \\
\text { techniques throughout } \\
\text { the field. }\end{array}$ & $\begin{array}{l}\text { Simplicity and accessibility of } \\
\text { use. }\end{array}$ & $\begin{array}{l}\text { There is a cutting of } \\
\text { weeds and their } \\
\text { incorporation into the } \\
\text { soil. Excessive or } \\
\text { insufficiently fertilized } \\
\text { areas. Economic } \\
\text { efficiency is uncertain. } \\
\text { Active degradation of } \\
\text { soils and landscapes. }\end{array}$ \\
\hline $\begin{array}{l}\text { Minimal } \\
\text { technology } \\
\text { (direct seeding). }\end{array}$ & $\begin{array}{l}\text { Includes one or a series of } \\
\text { small tillages with } \\
\text { cultivators or disc } \\
\text { harrows. Straw and } \\
\text { stubble are in the form of } \\
\text { mulch in the topsoil. The } \\
\text { seeding is carried out in } \\
\text { finely cultivated soil with } \\
\text { the creation of a mulching } \\
\text { layer of plant debris and } \\
\text { crumbly soil. }\end{array}$ & $\begin{array}{l}\text { Direct seeding is } \\
\text { carried out on stubble } \\
\text { without any tillage. } \\
\text { Minimization of soil } \\
\text { tillage. }\end{array}$ & $\begin{array}{l}\text { Reducing direct costs, reducing } \\
\text { fuel consumption by } 2-3 \text { times, } \\
\text { reducing labour costs by } 2.0-2.5 \\
\text { times. }\end{array}$ & $\begin{array}{l}\text { Deterioration of the } \\
\text { phytosanitary situation, } \\
\text { the need for pesticides, } \\
\text { increased mineral } \\
\text { nitrogen deficiency. } \\
\text { Differentiation of the } \\
\text { arable layer, the } \\
\text { impossibility of applying } \\
\text { organic fertilizers and } \\
\text { ameliorants. }\end{array}$ \\
\hline $\begin{array}{l}\text { Precision } \\
\text { agriculture. }\end{array}$ & GPS, Glonass system. & $\begin{array}{l}\text { Each agricultural field } \\
\text { is considered as } \\
\text { heterogeneous }\end{array}$ & $\begin{array}{l}\text { Ecological safety of the } \\
\text { environment, production of } \\
\text { products of a specified quality, }\end{array}$ & $\begin{array}{l}\text { High acquisition price. In } \\
\text { most } \\
\text { enterprises there is no }\end{array}$ \\
\hline
\end{tabular}




\section{ENTREPRENEURSHIP AND SUSTAINABILITY ISSUES}

ISSN 2345-0282 (online) http://jssidoi.org/jesi/

2020 Volume 7 Number 4 (June)

http://doi.org/10.9770/jesi.2020.7.4(41)

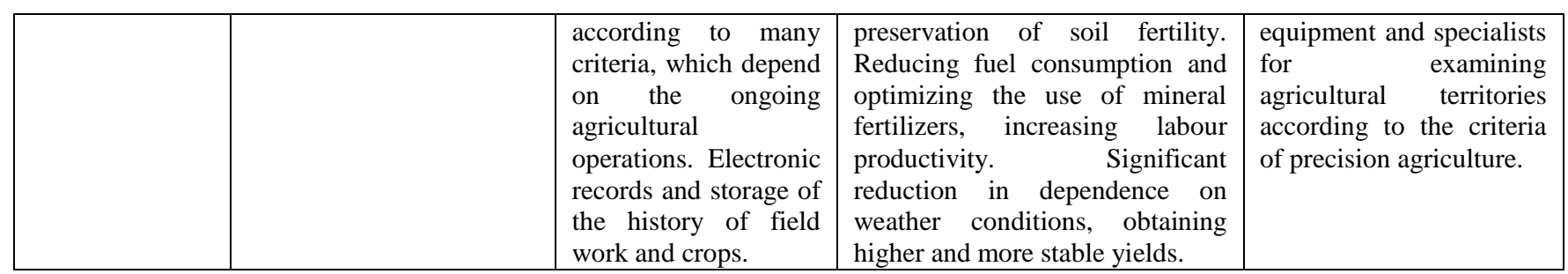

Precision agriculture includes many elements, but all of them can be divided into three main stages (Sharapov et al., 2014):

- Collection of data on the farm, field, crop, region.

- Analysis and decision making.

- Implementation of decisions - carrying out technological operations.

To implement the precision agriculture technology, modern agricultural equipment, controlled by an onboard computer and capable of differentially performing agro-technical operations, and precision positioning devices on the ground are required. Technical systems are needed to help identify field heterogeneity. All of the above entails the necessary costs, in connection with which, before making a decision on the introduction of precision agriculture elements, it is necessary to analyze the current state of the enterprise, as well as evaluate the material and technical support of the enterprise. The scheme is shown in the figure 1 below.

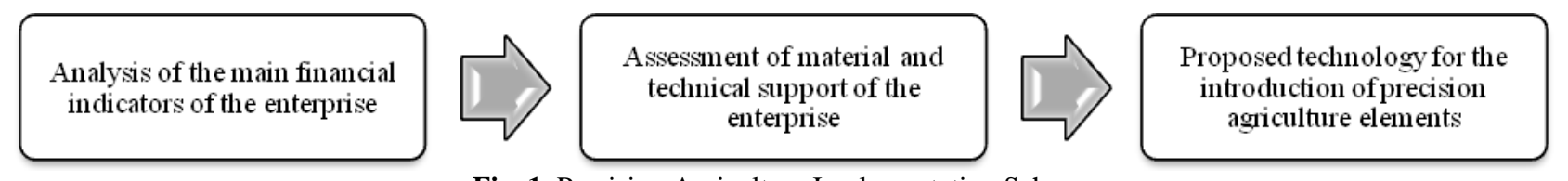

Fig. 1. Precision Agriculture Implementation Scheme

The basis of the technology of precision agriculture is software filling, which provides automated management of spatial attribute data of a card index of agricultural fields, as well as the generation, optimization and implementation of agricultural solutions, taking into account the variability of characteristics within the cultivated field.

The first stage in the implementation of precision agriculture technology is the development of a database that will contain information on the area, yield, agrochemical and agro-physical properties of the soil and the level of plant development. To collect information, automatic soil samplers equipped with GPS receivers and on-board computers; geographic information systems (GIS) for compiling spatially oriented electronic field maps; yield maps of threshed crops obtained immediately after harvesting; remote sensing methods (RSD), such as aerial photography and satellite imagery, are used.

The second stage is by far the least developed, however, there is a number of software products on the market designed to analyse the information collected and make production decisions. Decision support systems, expert systems, programmes that use mathematical models for the agricultural sector are just beginning to appear. Basically, these are programmes for calculating fertilizer doses with elements of geographic information systems (GIS).

At the third stage of the introduction of precision agriculture technology, the obtained and analyzed information is used when carrying out agro-technological operations, mainly in the differential application of fertilizers, when seeding. The stage of agro-technological operations, as well as the first stage, is developing dynamically. This stage is the most difficult. This stage is impossible without special equipment with on-board computers, GPSreceivers and various sensors that allow metering seeds and fertilizers, taking into account the needs of a 


\section{ENTREPRENEURSHIP AND SUSTAINABILITY ISSUES}

ISSN 2345-0282 (online) http://jssidoi.org/jesi/

2020 Volume 7 Number 4 (June)

http://doi.org/10.9770/jesi.2020.7.4(41)

particular section of the field. For more accurate operations, it is advisable to purchase a parallel driving system. Such devices allow you to perform agricultural operations even at night with an accuracy of several centimetres (Bikbulatova, 2008).

\section{Materials and Methods}

Precision agriculture is a set of separate technologies, the need for the implementation of which is determined at the discretion of the owners and managers of the agricultural enterprise. That is, it is possible to use both all technologies at once, or only some, the effect of which will be most significant for this enterprise (Genrikh et al., 2018).

A precision agriculture system is not a strictly defined set of techniques and technical means, but rather a general concept based on the use of satellite positioning technologies (GPS), geographic information systems (GIS), accurate mapping of fields, etc. (Galeev et al., 2019).

Orenburg scientists Lyubchich et al., (2013) distinguish 11 main stages for the development and implementation of precision agriculture systems:

1. parallel driving

2. cartography and topography of farmland,

3. yield mapping

4. soil sampling,

5. agrochemical soil analysis,

6. development of fertility maps,

7. development of job cards for the differential application of fertilizers (application of pesticides),

8. offline differentiated fertilizer application,

9. online differentiated fertilizer application,

10. online monitoring of agricultural machinery,

11. operating control of resources and precision enterprise management based on automated collection and processing of agro-technical data, accounting and planning.

The introduction of each of these stages of the precision agriculture system provides a more economical use of resources involved in agricultural production: labour, equipment and materials. This is the basis for the economic efficiency of the introduced elements of precision agriculture.

When conducting research, methods used in international practice were used: a review of sources, brainstorming, comparative analysis, SWOT analysis, a monographic method for determining economic efficiency, methods of mathematical modelling and other methods. To analyze the economic efficiency of simulated measures to increase the degree of technical equipment of precision agriculture with the elements of precision agriculture of the machine and tractor fleet of the enterprise under study, we determined the saving of current production costs due to the introduction of precision agriculture elements; the calculation of the indicator of the simple payback period required for such an investment is carried out. To calculate the effectiveness of information systems, a cost-benefit analysis was used. In cost-benefit analysis, monetary units are used to quantify costs and benefits. This type of analysis has a wider scope than other types of analysis, providing information on the distribution of resources between different sectors of the economy.

\section{Results}

The AES «Zarechnoye» LLP (Kostanay region, Kazakhstan) has always been the initiator of introduction and dissemination of advanced innovative technologies; in this regard, the agriculture has been identified as the basis for the introduction of digitalization elements, i.e. precision agriculture. 
In the framework of the scientific and technical programme «Transfer and adaptation of precision agriculture technologies for crop production on the principle of «demonstration farms (testing areas) in the Kostanay region», in 2019 work on the created demonstration farm at an area of 2500 hectares (ha) was continued in the AES «Zarechnoye» LLP.

In 2019, the AES «Zarechnoye» LLP digitized agricultural land using a digital platform «Qoldau» on a total area of 22,984.3 hectares, including hayfields and pastures (4,231.4 hectares). (See figure 2, figure 3, figure 4, figure 5, figure 6).

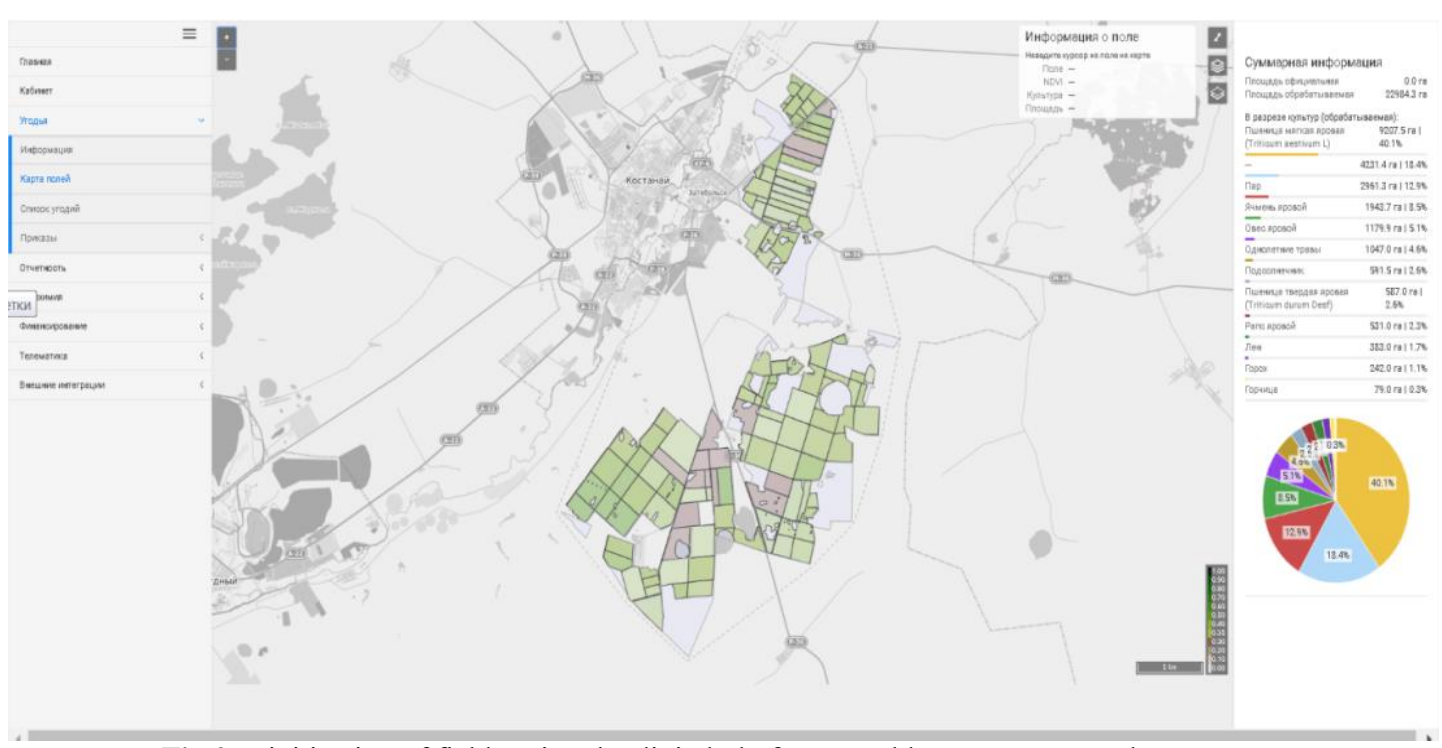

Fig.2. Digitization of fields using the digital platform «Qoldau», AES «Zarechnoye» LLP

To simplify the production processes in the cultivation of agricultural crops, the Agricultural Experimental Station «Zarechnoye» LLP uses the web-based crop management service ANT (AgroNetworkTechnologies). This service was developed by Russian specialists from the Krasnodar Territory and provided on the Kazakhstani market by Agrosmart KZ. The service is intended for large farms, because the larger the area under crops, the more difficult it is to manage them. ANT service is intended for chief and field agronomists, economists and record keepers, accountants (for work), as well as for managers and owners (for monitoring the work performed).

The main applications in the ANT system are: «My fields» (electronic field map); «Scouting» (agro-ecological surveys, field trips); «Agronotepad» (logging of technological operations and their parameters in the framework of events); «Seasons» (construction of crop rotation taking into account cultivated crops); «AHO» (agrochemical inspection of fields, analysis of the dynamics of nutrients in the soil); «Field passport» (the current state of the fields, taking into account the history of fields); «Satellite imagery» (identification of areas of heterogeneity using NDVI images for quick decision-making on plant protection and fertilizer application); «Meteo» (weather data and weather forecast by the weather station Caipos connected to the ANT service), etc. As practice has shown, the use of ANT service in production can reduce the cost of fertilizer application, plant protection products, the consumption rate of seeds, fuel, and, as a result, increase the profitability of agricultural production, as well as align the physical and agrochemical properties of the soil, which is directly relevant for agriculture of the steppe zone of Northern Kazakhstan. 


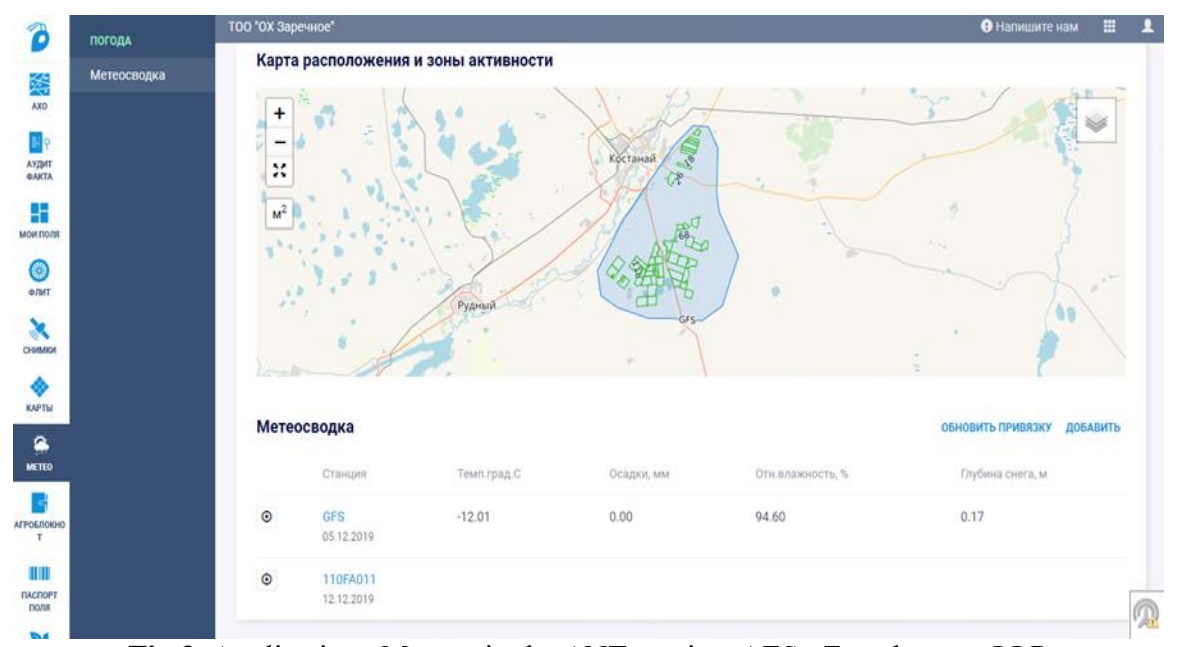

Fig.3. Application «Meteo» in the ANT service, AES «Zarechnoye» LLP

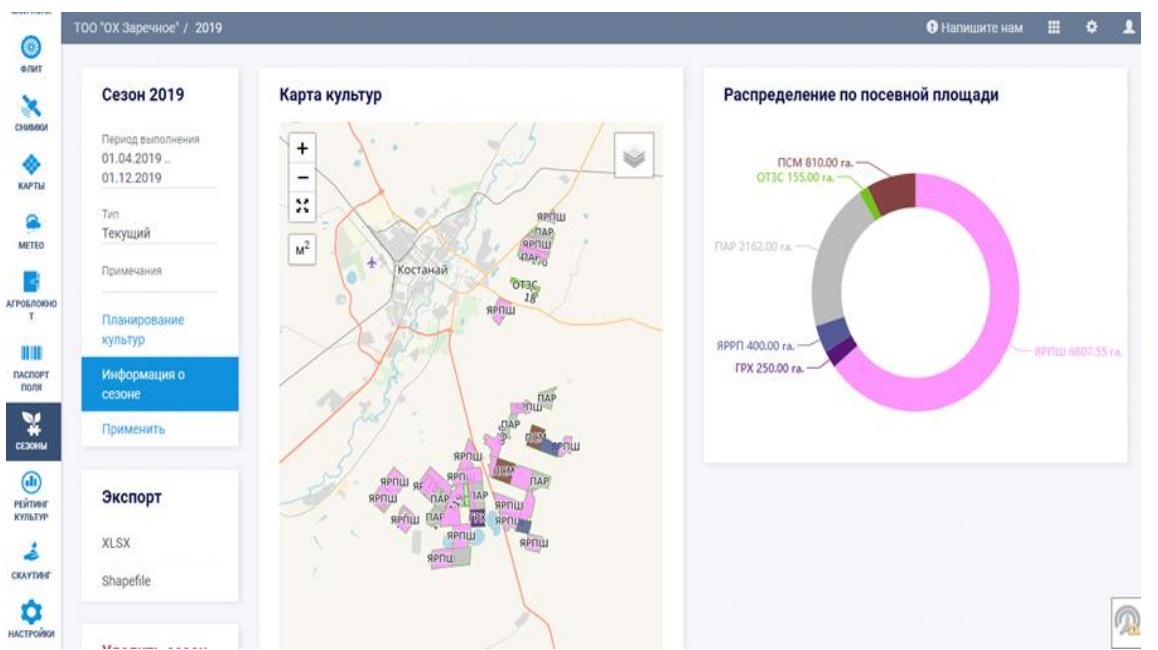

Fig.4. Formation of crop rotation structure according to the ANT service, AES «Zarechnoye» LLP

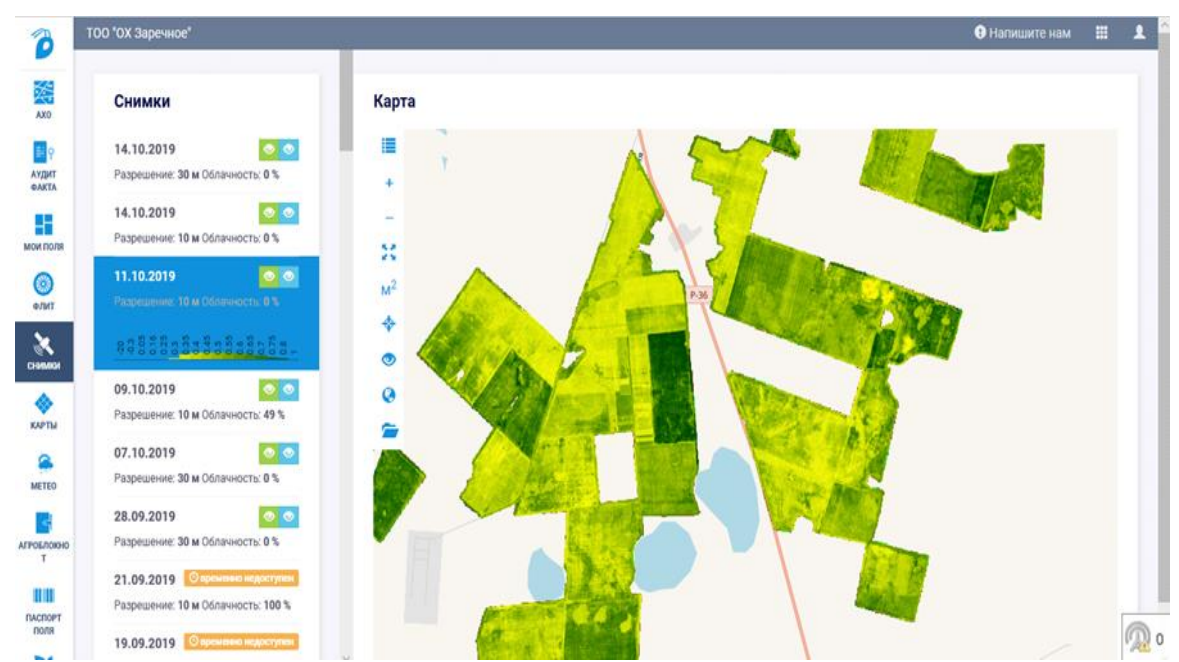

Fig.5. Satellite monitoring data allowing the analysis of heterogeneity in the field, AES «Zarechnoye» LLP 


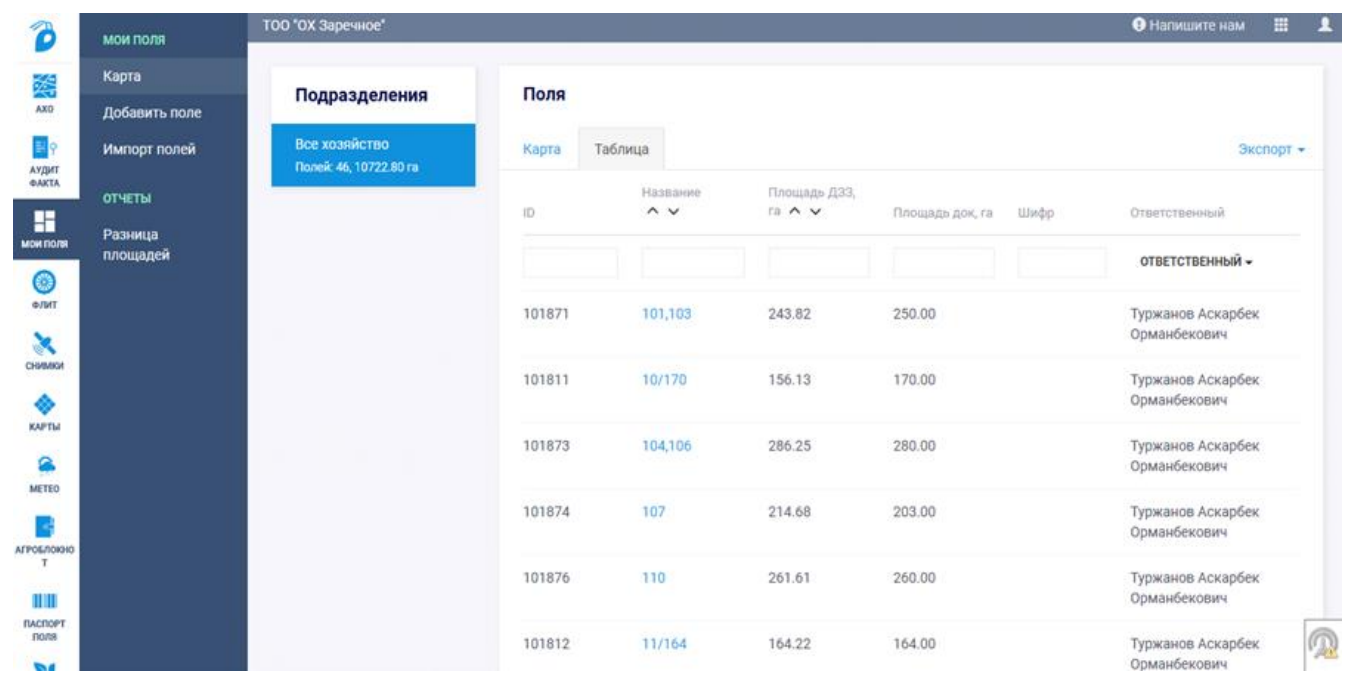

Fig.6. The register of fields allowing you to get field maps in electronic form, AES «Zarechnoye» LLP

The capabilities of the ANT service are quite extensive. Thanks to the ANT service, agricultural producers have the ability to remotely control the cultivated land and the structure of sown areas, the status of existing sown areas, plan crop rotation and technological operations in an autonomous mode, taking into account all agronomic processes. In addition, this service allows you to monitor all available equipment, save all information about a specific field for a long time, keep «Agronomist's Diary», and also create analytical data on production processes. At the testing area of AES «Zarechnoye» LLP, a sprayer John Deere 4730 equipped with an autopilot system and WeedSeeker system was used for the introduction of precision agriculture elements. Pre-seeding chemical treatment was carried out on the testing area. The use of an automatic driving system allowed to reduce the number of floors in 2019, thereby increasing the precision in movement of the unit along the lines and improving its performance. Thus, a saving of $6 \%$ glyphosate was achieved.

Using high-resolution satellite imagery, electronic maps of fields of the testing area were created in ArcGIS. A survey for the presence of field nutrients in the soil in elementary plots was carried out. In 2019, based on the data of the agrochemical survey of fields of the AES «Zarechnoye» LLP for 2018, maps of the availability of fields with humus, mobile phosphorus, exchange potassium, sulphur and nitrate nitrogen were created in QGIS 3.6. The development of job cards for differential application was carried out for nitrogen-phosphorus fertilizer of ammophos for spring wheat when seeding in accordance with the scale of soil supply with mobile phosphorus. Differential application of fertilizers was carried out by the seeding company Bourgault (Canada), which was specially equipped with an electric actuator for this purpose, and by the navigation complex Agronavigator-doser.

According to the data of the field flight with an unmanned aerial vehicle GeoScan 101, a map of the requirements for the differential application of foliar feeding was created. The application of a liquid mineral fertilizer Strada $\mathrm{N}$ was carried out during the tillering period with further tracking of all morphometric indicators. In 2019, the differentiated application of mineral fertilizers and foliar feeding significantly improved the economy of spring wheat grain production not only due to the difference in yield, but also due to the difference in the cost of products of different classes in quality.

The use of automated driving systems for seeding, chemical weeding, spring wheat harvesting and primary processing allows to increase productivity by $3.8-22.1 \%$, reduce fuel consumption - by $4.6-18.4 \%$, the consumption of technological material and total costs for the operation of technical equipment - by 3-14\%.

To draw up economic models for the implementation of precision technologies for the economy of the Kostanay region with medium technical equipment, the farm data of «Agrofirma Karkyn» LLP (Mendykara district, 
Kostanay region) were obtained and processed. This farm has about 25,000 ha of sown area, of which about 12,000 ha are sown with wheat.

The specified farm can be attributed to the category of farms with medium technical equipment, since the equipment fleet has equipment with integrated precision agriculture elements:

- tractors equipped with a parallel driving system, including a display Trimble GFX-750 with a navigation system NAV-900 Controller;

- all equipment is equipped with GPS trackers;

- all equipment is equipped with fuel level control systems.

Model No. 1. In the developed economic model No. 1, the transition of the machine and tractor fleet of the indicated farm to the next stage of precision agriculture will be simulated, which will give even greater resource savings, namely:

- introduction of an automatic driving system on tractors with a parallel driving system;

- introduction of parallel driving systems on the rest of the self-propelled machines involved in the main technological operations for wheat processing;

- introduction of a system of differential fertilizer application.

Table 2 shows data on the current state of technology and simulated transitions to the next stage of the introduction of precision agriculture in the farm according to Model No. 1.

Model No. 2. In the developed economic model No. 2, the transition of the machine-tractor fleet of the indicated farm to the next stage of precision agriculture will be simulated, which will give even greater resource savings, namely:

- introduction of automatic driving systems on all self-propelled machines involved in the main technological operations for wheat processing;

- introduction of a system of differential fertilizer application.

Table 3 shows data on the current state of technology and simulated transitions to the next stage of the introduction of precision agriculture in the farm according to Model No. 2. It simulates the option of equipping the agriculture machinery involved in the cultivation of wheat with automatic driving systems, as well as equipping seeding complexes with the system of differential fertilizer.

Table 2. Simulated equipment of farm machinery of «Agrofirma Karkyn» LLP for the transition to the next stage of precision agriculture according to Model No. 1

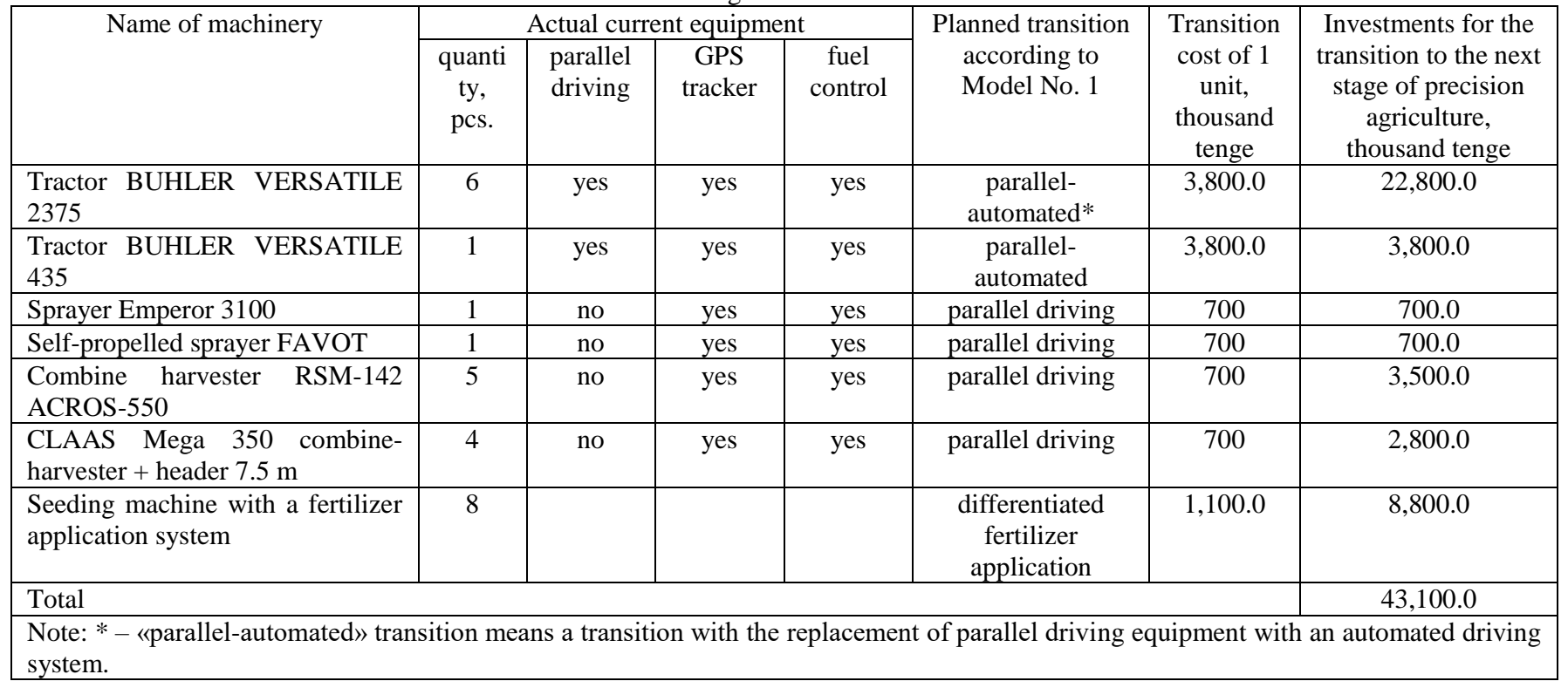




\section{ENTREPRENEURSHIP AND SUSTAINABILITY ISSUES}

ISSN 2345-0282 (online) http://jssidoi.org/jesi/

2020 Volume 7 Number 4 (June)

http://doi.org/10.9770/jesi.2020.7.4(41)

Table 3. Simulated equipment of farm machinery of «Agrofirma Karkyn» LLP for the transition to the next stage of precision agriculture according to Model No. 2

\begin{tabular}{|c|c|c|c|c|c|c|c|}
\hline \multirow[t]{2}{*}{ Name of machinery } & \multicolumn{4}{|c|}{ Actual current equipment } & \multirow{2}{*}{$\begin{array}{l}\text { Planned transition } \\
\text { according to } \\
\text { Model No. } 2\end{array}$} & \multirow{2}{*}{$\begin{array}{l}\text { Transition } \\
\text { cost of } 1 \\
\text { unit, } \\
\text { thousand } \\
\text { tenge }\end{array}$} & \multirow{2}{*}{$\begin{array}{l}\text { Investments for the } \\
\text { transition to the next } \\
\text { stage of precision } \\
\text { agriculture, } \\
\text { thousand tenge }\end{array}$} \\
\hline & $\begin{array}{l}\text { quanti } \\
\text { ty, } \\
\text { pcs. }\end{array}$ & $\begin{array}{l}\text { parallel } \\
\text { driving }\end{array}$ & $\begin{array}{l}\text { GPS } \\
\text { tracker }\end{array}$ & $\begin{array}{c}\text { fuel } \\
\text { control }\end{array}$ & & & \\
\hline $\begin{array}{l}\text { Tractor BUHLER VERSATILE } \\
2375\end{array}$ & 6 & yes & yes & yes & $\begin{array}{l}\text { parallel- } \\
\text { automated* }\end{array}$ & $3,800.0$ & $22,800.0$ \\
\hline $\begin{array}{l}\text { Tractor BUHLER VERSATILE } \\
435\end{array}$ & 1 & yes & yes & yes & $\begin{array}{c}\text { parallel- } \\
\text { automated }\end{array}$ & $3,800.0$ & $3,800.0$ \\
\hline Self-propelled sprayer FAVOT & 1 & no & yes & yes & parallel driving & $4,500.0$ & $4,500.0$ \\
\hline $\begin{array}{l}\text { Combine harvester RSM-142 } \\
\text { ACROS-550 }\end{array}$ & 5 & no & yes & yes & parallel driving & $4,500.0$ & $22,500.0$ \\
\hline $\begin{array}{l}\text { CLAAS Mega } 350 \text { combine- } \\
\text { harvester + header } 7.5 \mathrm{~m}\end{array}$ & 4 & no & yes & yes & parallel driving & $4,500.0$ & $18,000.0$ \\
\hline $\begin{array}{l}\text { Seeding machine with a fertilizer } \\
\text { application system }\end{array}$ & 8 & & & & $\begin{array}{l}\text { differentiated } \\
\text { fertilizer } \\
\text { application } \\
\end{array}$ & $1,100.0$ & $8,800.0$ \\
\hline
\end{tabular}

Next, we will build economic models for the transition to the next stage of the introduction of precision agriculture elements in «Agrofirma Karkyn» LLP and calculate the project payback by saving the cost of growing wheat on 12,000 hectares.

The economic model implies the use of cost-saving factors used in modelling the transition to the next stage of precision agriculture in calculating the costs of the technological map for growing wheat. Thus, potential savings will be calculated.

Increasing productivity in simulating the transition to the next stage of precision agriculture leads to lower costs. Cost savings in this case can be used to ensure a return on investment in ensuring the modernization of technology for the transition to the next stage of precision agriculture.

Table 4 shows the calculation of the simple payback period for investments in the modernization of the equipment fleet of «Agrofirma Karkyn» LLP according to two models of transition to the next stage of precision agriculture.

Table 4. Calculation of a simple payback period for the transition to the next stage of precision agriculture

\begin{tabular}{|l|c|c|}
\hline \multicolumn{1}{|c|}{ Indicator } & $\begin{array}{c}\text { According to } \\
\text { Model No. } 1\end{array}$ & $\begin{array}{c}\text { According to } \\
\text { Model No. 2 }\end{array}$ \\
\hline Investments for the transition to the next stage of precision agriculture, thousand tenge & $43,100.0$ & $84,900.0$ \\
\hline $\begin{array}{l}\text { Potential cost savings from the introduction of a simulated transition to the next stage of } \\
\text { precision agriculture, thousand tenge }\end{array}$ & $15,225.8$ & $19,360.5$ \\
\hline Simple payback period, years & 2.8 & 4.4 \\
\hline
\end{tabular}

Thus, a partial transfer of equipment to a parallel driving system, the introduction of a differential fertilizer application system and the modernization of tractors with automated driving equipment according to Model No. 1 will make it possible to recoup the investment by saving costs for 2.8 years. In this case, the total cost savings will be 15.2 million tenge or $3.1 \%$ of direct production costs for growing wheat. 
ENTREPRENEURSHIP AND SUSTAINABILITY ISSUES

ISSN 2345-0282 (online) http://jssidoi.org/jesi/

2020 Volume 7 Number 4 (June)

http://doi.org/10.9770/jesi.2020.7.4(41)

\section{Discussion}

Simulated improvements in the transition of Agrofirma Karginy LLP to the next stage of precision agriculture will save the following costs:

- labour costs for drivers due to an increase in the production of norm-change due to a decrease in the overlap area during coverage;

- fuel costs due to a decrease in specific fuel consumption due to a decrease in the overlap area during coverage;

- costs of seeds, herbicides, water and other materials for processing due to the reduction in the overlap area during coverage;

- costs due to a decrease in the actual dose of mineral fertilizers when introducing a system of differential fertilizer application.

The introduction of the next stage of precision agriculture in the studied farm when processing wheat on 12,000 hectares according to Model No. 1 will save up to 15.2 million tenge annually or $3.1 \%$ of direct production costs. Cost savings per 1 ha of cultivated arable land in this case will be 1264 tenge. The savings from the introduction of Model 2 will amount to 19.36 million tenge from processing 12,000 hectares of wheat or $4.0 \%$ of production costs. This is 1607 tenge per 1 hectare of arable land.

\section{Conclusion}

The use of elements of the precision agriculture system (differential seeding and fertilizing, foliar feeding using digital devices, using an information-analytical system, Earth remote sensing (ERS) using unmanned aerial vehicles and satellite images), using modern technology equipped with an automatic driving system, a system of differential application of mineral fertilizers and plant protection products by AES Zarecnoye LLP ensured a guaranteed yield with high technological indicators in an extremely arid year in the conditions of the Kostanay region. The obtained yield level exceeded the average regional level by $79.7 \%$.

The equipment of all self-propelled machinery of «Agrofirma Karkyn» LLP, involved in the basic production operations with automated driving systems and the introduction of a differential fertilizer application system, according to Model No. 2, will make it possible to recoup the investment in 4.4 years. According to this model, total cost savings will amount to 19.36 million tenge or $4.0 \%$ of direct production costs.

\section{Acknowledgments}

This article has been prepared based on the results of the research conducted as part of the scientific and technical programme No. BR06349568 "Transfer and adaptation of precision agriculture technologies for crop production on the principle of «demonstration farms (testing areas)» in the Kostanay region», funded by the Ministry of Agriculture of the Republic of Kazakhstan for 2018-2020.

\section{References}

Abuova, A.B., Tulkubayeva, S.A., Tulayev, V.Y., Somova, S.V., Tashmukhamedov, M.B. (2019). The technology of cultivating agricultural crops based on ortho photomaps, digital and 3-D surface models. International Journal of Engineering and Advanced Technology, 8(4), 775-778.

Agriculture, forestry and fisheries in the Republic of Kazakhstan. Statistical compilation. Astana, 2013. 217 p.

Allahyari, M., Mohammadzadeh, M., Nastis, S. (2016). Agricultural experts' attitude towards precision agriculture: Evidence from Guilan Agricultural Organization, Northern Iran. Information Processing in Agriculture, 3(3), 183-189. 


\section{ENTREPRENEURSHIP AND SUSTAINABILITY ISSUES}

ISSN 2345-0282 (online) http://jssidoi.org/jesi/

2020 Volume 7 Number 4 (June)

http://doi.org/10.9770/jesi.2020.7.4(41)

Baerdemaeker, J.D. (2013). Precision agriculture technology and robotics for good agricultural practices. IFAC Proceedings. Volume 46. pp.1-4.

Bikbulatova, G.G. (2008). Precision agriculture technology. Omsk Scientific Bulletin. Omsk: Omsk State Technical University. 2 , 45-59.

Catalog of tractor factories, manufacturers of tractor equipment [Electronic resource], Russian tractor server http://www.traktor.ru Screen title.

Far, S.T., Rezaei-Moghaddam, K. (2018). Impacts of the precision agricultural technologies in Iran: An analysis experts' perception \& their determinants. Information Processing in Agriculture, 5(1), 173-184.

Galeev, E.I., Ishbulatov, M.G. (2019). The role of cartography for precision agriculture. Bulletin of the Bashkir State Agrarian University. Ufa: Bashkir State Agrarian University, 2 (50), 21-26.

Genrikh, A.A., Myalo, V.V., Demchuk, E.V. (2018). Precision agriculture. Scientific innovations to agricultural production: materials of the International scientific-practical conference dedicated to the 100th anniversary of the Omsk State Agrarian University. Omsk: P.A. Stolypin Omsk State Agrarian University, pp.103-106.

Goltyapin, V.Ya. (2013). Systems of parallel driving of machine-tractor units. Technique and equipment for the village, $11,12-14$.

Higgins, V., Bryant, M., Howell, A., Battersby, J. (2017). Ordering adoption: Materiality, knowledge and farmer engagement with precision agriculture technologies. Journal of Rural Studies, 55, 193-202.

Hmiminaa, G. et al. (2013). Evaluation of the potential of MODIS satellite data to predict vegetation phenology in different biomes: An investigation using ground-based NDVI measurements. Remote Sensing of Environment, 132, 145-158.

Kurishbaev, A.K., Nukeshev, S.O. (2012). Prospects for the technology of differentiated use of mineral fertilizers in the conditions of Northern Kazakhstan. Integrated development of rural territories and innovative technologies in the agricultural sector: Materials of an international conference. Novosibirsk, pp.181-185.

Leonard, E.C. (2016). Precision Agriculture. Encyclopaedia of Food Grains (Second Edition). Volume 4, 162-167.

Lichman, G.I., Smirnov, I.G., Lichman, A.A., Belenkov, A.I. (2016). Fundamental and applied research in precision agriculture: main directions. Niva Russia, 9, 74-76.

Lyubchich, V.A., Kuramshin, M.R. (2013). The use of telematic terminals for monitoring agricultural machinery in precision agriculture. Niva Zauralye, 6(106), 62-64.

Maes, W.H., Steppe, K. (2019). Perspectives for Remote Sensing with Unmanned Aerial Vehicles in Precision Agriculture. Trends in Plant Science, 24(2), 152-164.

Mitrofanov, E.P., Petrushin, A.F., Mitrofanova, O.A. (2018). The use of aerial photography data to justify precision agricultural practices for the use of agrochemicals. Materials of the 2nd All-Russian scientific conference with international participation «The use of Earth remote sensing in agriculture». - St. Petersburg: FSBIU AFI, 197-202.

Nukeshev, S., Dzhadyger, E., Karaivanov, D. (2014). Determination of parameters of the main distributor for fertilizer applying machine. Bulgarian Journal of Agricultural Science, 20(6), 1513-1521.

Nukeshev, S.O., Yeskhozhin, D.Z., Romanyuk, N.N., Akhmetov, E.S., Yeskhozhin, K.D., Zolotukhin, E.A., Tleumbetov, K.M. (2015). Some results of experimental studies of the metering system of a grain-fertilizer machine with a control and management unit. Vestnik Nauki KATU im. S.Seifullina (interdisciplinary), 1(84), 198-208.

Pestunov, I.A., Melnikov, P.V., Rylov, S.A. (2018). Automated assessment of crop seedlings from survey data from unmanned aerial vehicles. Materials of the 2nd All-Russian Scientific Conference with international participation «The use of Earth remote sensing in agriculture». St. Petersburg: FSBIU AFI, pp.253-260. 


\section{ENTREPRENEURSHIP AND SUSTAINABILITY ISSUES}

ISSN 2345-0282 (online) http://jssidoi.org/jesi/

2020 Volume 7 Number 4 (June)

http://doi.org/10.9770/jesi.2020.7.4(41)

Polshakova, N.V. (2017). Food sovereignty of Russia: prospects for the introduction of precision agriculture technologies in adaptivelandscape agriculture systems // Collection of articles of the 7th International Scientific and Practical Conference: in 2 parts. Penza: Science and Enlightenment, pp.186-188.

Sharapov, I.V., Pronin, S.P. (2014). Methods of optical control of the yield of local sections of the field in precision agriculture. Polzunovsky Almanac. Barnaul: I.I. Polzunov Altai State Technical University, 1, 166-169.

Shilova, N.V. (2014). On the need to introduce a precision agriculture system in grain production. Models, systems, networks in economics, technology, nature and society. Penza: Penza State University, 4(12), 93-98.

Shpaar, D. et al. (2009). Precision Agriculture / Edited by D. Shpaar, A.V. Zakharenko, V.P. Yakusheva. St. Petersburg: Pushkin. 397 p.

Spitkó, T., Nagy, Z., Zsubori, Z.T., Szőke, C. et al. (2016). Connection between normalized difference vegetation index and yield in maize. Plant Soil Environment, 62(7), 293-298. doi: 10.17221/676/2015-PSE.

Srivastava, K., Bhutoria, A.J., Sharma, J.K., Sinha, A., Pandey P.C. (2019). UAVs technology for the development of GUI based application for precision agriculture and environmental research. Remote Sensing Applications: Society and Environment. Volume 16. Article 100258 .

Sychev, V.G. (2011). Information and technological support of precision agriculture / V.G. Sychev, R.A. Afanasyev, A.Yu. Izmailov et al. Plodorodie (3), 44-47.

Truflyak, E.V. (2016). Experience in the application of precision agriculture systems / E.V. Truflyak. - Krasnodar: KubSAU. - 22 p.

Truflyak, E.V., Trubilin, E.I. (2016). Intelligent technical means of agriculture. - Krasnodar: KubSAU. - 266 p.

Truflyak, E.V., Trubilin, E.I., Buksman, V.E., Sidorenko, S.M. (2015). Precision Agriculture. - Krasnodar: KubSAU. - 376 p.

Tugarinov, L.V., Zherebin, P.M., Petrushin, A.F., Muntyan, A.N. (2018). Prospects for field experiments on the introduction of crop correction tools using data from Earth remote sensing. Materials of the 2nd All-Russian scientific conference with international participation «The use of Earth remote sensing in agriculture». St. Petersburg: FSBIU AFI, pp.209-213.

Yakushev, V.P. (2002). On the way to precision agriculture. St. Petersburg: PNPI RAS. 458 p.

Yakushev, V.P. (2007). Information support of precision agriculture / V.P. Yakushev, V.V. Yakushev. St. Petersburg: PNPI RAS. 382 p. 


\title{
ENTREPRENEURSHIP AND SUSTAINABILITY ISSUES
}

ISSN 2345-0282 (online) http://jssidoi.org/jesi/

2020 Volume 7 Number 4 (June)

http://doi.org/10.9770/jesi.2020.7.4(41)

\begin{abstract}
Altynay B. ABUOVA, Associate Professor, Doctor of Agricultural Sciences, Zhangir Khan West Kazakhstan Agrarian-Technical University, Institute of Agricultural Technology, Higher School of Food and Food Processing Technologies. Professional interests: research in the field of agriculture and processing of crop products, quality and safety of crop products, technology for the cultivation of oilseeds, precision agriculture. Recent articles are published in collaboration with research colleagues in agriculture, precision agriculture, the use of GIS technology, transition to and the introduction of precision agriculture elements.
\end{abstract}

ORCID ID: https://orcid.org/0000-0002-1987-8417

Saniya A. TULKUBAYEVA, Candidate of Agricultural Sciences, Scientific Secretary, Agricultural experimental station «Zarechnoye» Limited Liability Company

Professional interests: research in the field of agriculture, oilseed cultivation technology, precision agriculture. Recent articles are published in collaboration with research colleagues in agriculture, precision agriculture, the use of GIS technology, transfer and the introduction of precision agriculture elements.

ORCID ID: https://orcid.org/0000-0003-1548-6982

Yuriy V. TULAYEV, Head of the Laboratory for Precision and Organic Agriculture, Agricultural experimental station «Zarechnoye» Limited Liability Company

Professional interests: agricultural research, conservation agriculture, organic agriculture, precision agriculture. Recent articles are published in collaboration with research colleagues in agriculture, precision agriculture, the use of GIS technology, transition to and the introduction of precision agriculture elements.

ORCID ID: https://orcid.org/0000-0003-1065-8968

Svetlana V. SOMOVA, Senior Researcher, Laboratory of Precision and Organic Agriculture, Agricultural experimental station «Zarechnoye» Limited Liability Company

Professional interests: agricultural research, conservation agriculture, organic agriculture, precision agriculture. Recent articles are published in collaboration with research colleagues in agriculture, precision agriculture, the use of GIS technology, transition to and the introduction of precision agriculture elements.

ORCID ID: $\underline{\text { https://orcid.org/0000-0003-1823-2240 }}$

Maigul Zh. KIZATOVA, Doctor of Technical Sciences, Professor, S. Asfendiyarov Kazakh National University.

Professional interests: research in the field of processing agricultural crop products, quality, safety of innovative food products. Recent articles are published in collaboration with research colleagues in agriculture, precision agriculture, the use of GIS technology, transition to and the introduction of precision agriculture elements.

ORCID ID: $\underline{\text { https://orcid.org/0000-0002-6481-7410 }}$

Register for an ORCID ID:

https://orcid.org/register

Copyright (C) 2020 by author(s) and VsI Entrepreneurship and Sustainability Center

This work is licensed under the Creative Commons Attribution International License (CC BY).

http://creativecommons.org/licenses/by/4.0/

c) (†) Open Access 